\title{
Tribalism, Politics and Hate Discourse in Contemporary Cameroon English; a Linguistic Usurpation
}

\author{
Willie Mushing Tamfuh \\ The Department of English, Faculty of Arts, Letters and Social Sciences, The University of Ngaoundere, Ngaoundere, Cameroon
}

\section{Email address:}

mustamwill@yahoo.fr

\section{To cite this article:}

Willie Mushing Tamfuh. Tribalism, Politics and Hate Discourse in Contemporary Cameroon English; a Linguistic Usurpation. Communication and Linguistics Studies. Vol. 6, No. 3, 2020, pp. 47-64. doi: 10.11648/j.cls.20200603.12

Received: September 26, 2020; Accepted: October 12, 2020; Published: October 21, 2020

\begin{abstract}
In our time, casual conversations and political speeches as well as written productions in English in Cameroon are, to a greater extent, replete with ugly expressions full of sheer cloudy vagueness, inaccurate and debased language, consisting largely of euphemisms, pretentious dictions and sometimes meaningless words that depict a people's experiences of resentment and bitterness as a result of tribalism and hatred. This investigation sets out to observe manifestation of tribalism and hatred in their speech, and to collect typical communicative acts in this light, analyze these as manifestations of tribalism and hate speech acts in contemporary Cameroon English speech. The objective is analyse this form of linguistic impoliteness in order to denounce and decry its devastating stigmatizing effects on living together and national integration, and which if not checked early and appropriately constitute a time-bomb. Different linguistic, sociological, ethnomethodological and psychological methods have been used to collect quantitative and qualitative data from informants, and analyze based on well-established sociological and pragmatic theories referred to as sociopragmatics; one of which is the critical discourse analysis that identifies and exposes the ways in which language, political ideology and tribal power are constantly instantiated and enacted in the everyday conversational discourse in Cameroon, politics and the media. It is important to be note that the words we use have power. Often, speakers are not conscious that the words they use does influence and affect the listener's thoughts, actions, moral and emotional state and feelings, perception, hence his general behaviour. After the analysis, findings reveal that love for one another, decent speech, and upholding of human moral values are needful among Cameroonians. It builds human relations, mutual self-respect and a stronger nation. Nevertheless, from a purely linguistic perspective, tribalism and hatred have enriched contemporary Cameroon English vocabulary. In conclusion, a multilingual and culturally diversified nation as Cameroon needs a more inclusive participation of all the people for the construction of a better society.
\end{abstract}

Keywords: Tribalism, Politics, Media, Hate, Contemporary English, Usurpation

\section{Introduction}

Language use is something specific to human beings and distinguishes man among all other living things. The use of language makes it possible for individuals living in a society to live together, express their ideas, feelings, emotions, and beliefs freely. To millions of speakers, the English language is not our mother's language, but as far as are we into it, we try our best in using it the right way. English language, as simple as it is, could be sometimes misused without selfknowing that the words employed are inaccurate and hurting in themselves. True, no one is perfect that he may not make mistakes. But sometimes, out of confusion, hatred and frustration, it is misused or mistaken; tribalism can be mistaken for patriotism, politics for impoliteness, love for one another for hatred between people. Certain situations may push one to mistake love for hatred. So intimate is the relationship between tribalism, politics and hate speech in modern Cameroonian society that the three concepts can scarcely be thought of apart in English speech. The language serves as the communication code by which humans express their ideas, feelings, emotions and the harboured attitudes.

The English language is one of the most important languages used in the world for communication. Other languages are important too no doubt, but not for the same reasons because English, as a means of communication, truly 
links the whole world together.

If not that English is used in such domains as diplomacy, communication technology, commerce, science, casual conversations and speeches, the world may not be as united as it is today.

Pennycook et al, [1] in a controversial research on innovations and challenges of the English language today emphasize on the critical awareness people need of their language; arguing that the imperialist expansion of the English language has been at the cost of local languages in many countries. Not surprisingly, his views have been contested by those who regard the development of a wide variety of Englishes around the world is evidence that English no longer belongs to the English-nor even to the Americans. The case of contemporary English used in a multilingual and culturally diversified country like Cameroon is no exception.

After World War 1 and the German defeat, Cameroon was mandated to France and Britain by the League of Nations under its trusteeship in June 28, 1919. The French Cameroon, gaining their independence in 1960 and the British Cameroon in October 1961 respectively, a system of indirect rule through the tribal chiefs as auxiliary administrators was practiced in British territories, while the French practiced a policy of assimilation, aimed at transforming Cameroonians into subordinating them as second-class Frenchmen. In the territory under British mandate, several indigenous languages like Bafut, Duala, Kenyang and Mungaka alongside with English, were used in the administration and taught in schools (Bitja'a) [2] as British administrators needed to work with the local population and local chiefs a leitmotiv for the development of nationalism.

In 1961, during the Foumban conference the Constitution was negotiated and through a gentlemanly agreement, the two territories came together, adopted English and French as official languages of the Republic of Cameroon. ${ }^{1}$ and the language policy whereby English and French were inscribed in the constitution. ${ }^{2}$ The idea of creating a single political unit or country out of these diversified tribes was originally a British concept, which, till date, has been struggling to find its feet, but is foiled by the differences in cultures, languages, values, conspiracy, tribalism and mutual dislike.

Considered the world's 54th largest country, the amazing fact lies in Cameroon's multilingual nature with two official languages, English and French, a Cameroon pidgin English (CPE), and over 275 established dia-lects making it a linguistic paradise. According to the 2017 SIL international rankings by country, Cameroon occupies the $2^{\text {th }}$ position as the most linguistically diversified country in the world with a

\footnotetext{
1 For more on this, see Cameroon history and the famous Foumban Conference and the Reunification of Cameroon consolidated on 1 October 1961 through the Reunification of Cameroon and the creation of the Federal Republic of Cameroon. 2 For more on this, see Art. 1, Par 3. of the Cameroon Constitution of 18 January 1996: The official languages of the Republic of Cameroon shall be English and French, both languages having the same status. The State shall guarantee the promotion of bilingualism throughout the country. It shall endeavour to protect and promote national languages.
}

linguistic diversity index of 0.974 out of 232 countries in the UNESCO World Report investing in cultural diversity and intercultural Dialogue. However, the distinction between a language and a dialect is fluid and often political. A great number of languages are considered to be dialects of another language by some experts and separate languages by others.

Nevertheless, Cameroon has more than 300 tribes dispersed in three main ethnic groups; the Bantus, SemiBantus and Sudanese. Note that Cameroon is the $6^{\text {th }}$ most ethnically and culturally diversified country in the world with about 250 ethnic groups. This figure, advanced by Breton and Fohtung's [3] study is re-echoed by Boum Ndongo Semengue and Sadembouo [4]. Yet, recent statistics published by Summer Institute of Linguistics (SIL) in Ethnologue [5] credits Cameroon with 275 indigenous languages. Though these figures, Wolf [6] argues, have been under challenge as not being an accurate reflection of the current language situation, Cameroon's linguistic situation renders language use quite complex with English, French, Cameroon Pidgin English (CPE) and some dialects used interchangeably and accepted by a great majority of Cameroonians. An educated Wimbum speaks and understands English, French, CPE, Limbum and Fulfulde. Nowadays, Basaa is not only spoken by those from littoral, but by Basaaphones in the Littoral and Centre regions. Equally, Bulu or Ewondo is used by the Fang-Beti in the Centre, South and East regions, and Dualaphone used by some ethnic groups that belong to the Sawa group like the Bakweri and the Bakossi in the South-West regions, as well as the Mbo in the Littoral region; Fulfulde is used in the three northern regions, but today, it is also spoken in the northwest as well as in other parts of Cameroon; Mungaka is used in the North-West region including Balikumbat, Bali nyonya etc. When speakers of different languages come into constant contact and interact closely with others, they tend to borrow words used from the other language in their speech. Children easily learn to speak other languages in the school environment because they are daily contact with speakers of these languages. Cameroon's linguistic diversity, to a greater extent, is the result of its history and culture. The Sample data of spoken and written languages for this investigation has been collected from Cameroonians who speak and understand at least three languages.

In spite of the fact that English and French are considered to be equal in status as per the Constitution, French has a de facto dominance over English in the areas of administration, education, the military, and the media. It is not an exaggeration to say that French has greatly influenced language, culture and politics in all domains (Wolf) [7], attributed to the demographic reality, and the fact that certain members of particular tribes have continued to occupy top ranking positions in power to the dissatisfaction of members of other tribes, regions, communities and minority groups, promoting tribalism. Though belonging to a tribe is to claim a sense of belonging and identity, and Cameroon has dozens of tribal and linguistic groups, most of which are very small, tribalism is, however, a pejorative concept. But it is not the 
small groups that promote the spirit of tribe over nation, causing trouble, it is the rivalry between groups of administrative and local elites from these tribes, vying for political supremacy, positions and fringe benefits. Of course, to a greater extent, this situation has left members of other regions, communities, minority groups or tribes to feel excluded, hated, marginalized, frustrated, insecurity and uncertain of their social identity and believe they are cohabiting an hostile environment to them (Wolf) [7]. Seemingly, where the government considered official bilingualism in Cameroon a factor of national integration, the impression today is that it tends to create an Anglophone/Francophone divide, frustration and hatred in recent years which constitute serious challenges to living together, nation building, peace and unity. While statements such as anglo, Bamenda, terrorist, come-no-go, Béti, Bami, etc., are used to identify one's social identity or tribe in Cameroon, they are equally derogatory, intolerant, stigmatizing, provoke anger and incite hatred and violence thereby legitimizing acts of hatred, disunity or conflict. The trouble with tribalism is not so much the fact that they dislike each other. The issue is that they are competing for such scarce commodities as positions, jobs, scholarships and other sinecure favours. The group which controls the state controls the job.

The idea is that though language use is a mental activity, it is also a form of social behaviour. Skinner's [8] view on this subject were slightly less extreme than those of his predecessors, who believed that we do have such a thing as a mind that enables man to think, but that it is simply more productive to study observable and concrete behavior rather than internal mental events. Behaviorism is a theory of learning which states that all behaviours are learned through interaction with the environment in a process called conditioning. While Skinner [8] focused on the language people were observed using, Chomsky [9] was interested in studying the underlying structure of language. Thus, behavior is simply a response to environmental stimuli. Behaviorism, as the dominant approach to language at the time, was no longer to be the way of studying language.

This shift in focus affected not only how we view the structure of language, but how it might be studied as well; the data used to test these hypotheses are native speakers' intuitions on the grammatical and ungrammatical nature of the sentences of their language: What we study is what people implicitly know about their language. We do not study whether sentences abide by the rules of grammar, but whether grammatical and ungrammatical sentences can be explained with the hypotheses we make. By examining the native speakers' underlying knowledge, we can get a better understanding of how the mind works: language use being a window into the speaker's mind.

The study of the historical, political and social events over a long period in Cameroon reveals several important changes, notably an upsurge in tribalism and a decline of the free style language is used daily. Many attribute this free style to the recent wave of democracy that has ushered in freedom of speech, movement, and political reforms, which has also provoked a laissez-faire society, multiparty politics and the unquenchable thirst for power lack of rigour, as well as moral and linguistic decadence. In such general atmosphere, language must suffer and the consequence is the debasement in language used by the people. No wonder, therefore, that tribal passions run high in politics and becomes a threat to living together, moral integrity, and peaceful society. Tribalism has become the basis for hatred between peoples within the same country, a situation manifested in tribal politics, and which, if not well handled early enough, might constitute a time-bomb and a threat to national integration. Never has such misconceptions as tribalinguistics and hate discourse been the essence of building a strong Cameroon nation, but have all fueled the upsurge of hatred in Cameroon, promoting multi- misapprehensions and pitting members of one language or tribal group, clan, or village against others speakers (who feel marginalized, mocked, oppressed, social injustice, etc.). Schwarz [11] and Rotberg [12] examined the subject of tribalism and politics in Africa notably in Nigeria and Zambia respectively affirming that both concepts are hardly separable.

Orwell [13] in an essay on Politics and the English Language, examined the written English style of his time and establishing the connection between political orthodoxies and the language used, criticizes the English "ugly and inaccurate" and concluded that there is the debasement of language. He held that language is a political issue, and slovenly use of language and cliches make it easier for those in power to deliberately use misleading language to hide unpleasant political facts.

In our time, casual conversations and political speeches as well as written productions in English are, to a greater extent, replete with ugly, inaccurate and debased language, consist largely of euphemisms, pretentious dictions and sometimes meaningless words and utterances to depict experiences of resentment and bitterness as a result of the speaker's deep emotions. The insincerity of the speakers perpetuates the decline of the language as people (particularly politicians), use expressions with sheer cloudy vagueness. Fairclough's research uses the critical discourse analysis approach to identify and expose the ways in which language, ideology and power are constantly instantiated and enacted in the familiar discourse of the media and everyday social interactions.

Challenges of embezzlement, corruption, electoral fraud, social injustice, moral decadence, terrorism, human rights abuse, the Anglophone crises, tribalism and hate discourse are burning issues that affect the life of the Cameroonian people and consequently are frequent heard in casual conversations, political speeches and on the Cameroon media landscape.

The importance of studying the state of the English language in Cameroon today is inestimable. English language, as simple as it is, could be misused by its users without selfknowing that the words are inaccurate and hurting. Language, like style, is never simply a question of aesthetics; it is 
always inextricably linked to politics and to truth. In his opinion, all issues are political issues, and politics itself is a mass of lies, evasions, folly, hatred and schizophrenia Orwell [13]. He expresses disappointment on the deterioration of the English language and how politics is a cause for the "vagueness and incompetence" that writing has succumbed too, notes Orwell [13] Language is a political issue, and slovenly use of language and cliches make it easier for those in power to deliberately use misleading language to hide unpleasant political facts.

English can even be said to be the single most important language in the world. Yes, other languages are important though, but not for the same reasons as English. The modern point of view of linguistics regards language not just as a means of individual self-expression in conversational exchanges and communication, but the use of it, even though it is produced by the individual, is the property of the society and an act of social behaviour and the instrument of society. Hatred denotes a human condition or emotional state of intense dislike, detestation, loathing, despising, hostility, enmity, ill will, animosity, antagonism and aggression towards someone or a group of people that demands action.' The expression Aucun Bamileke ne sera jamais à Etoudi.. ${ }^{3}$ It may come as a conditioned emotional response (CER), of anger, choleric, fear, fright. For example, Atanga Nji s'attaque à MTN et Orange, Kamto + Atanga Nji, Duel de Sang' where the verbs 'attack' and 'duel' are a subterfuge for hatred, including abhorrence, rancor, heartburning, sulkiness, grudge, score-settling, grievance, envy, malevolence, malice, vindictiveness, and vengefulness. It is important to note that such synonyms describe a speaker's emotional state of mind using words that manifests hate discourse between both personalities. A language is a certain system of habits and skills; to know a language is to have mastered these skills. By examining the speakers' underlying knowledge, we get a better understanding of how the mind works: language is a window into the mind. In as much as society influences the way we use language, the choice of the words frequently heard or read equally influences the society. It reveals the people's thought, social behavior and perception.

When speakers of different languages interact closely, their languages to influence each other. In the public service, workers have to share office space and interact with coworkers and the general public. Here, the function of language is phatic communion intended to socialize, exchange ideas, emotions and feelings, agree or disagree, share ideas and ensure smooth communication with respect to certain established norms of social interaction, notably the Co-operative principles in conversations. When people live together, they think together in terms of tribal affiliations, they speak and behave in like manner. Language use refers to the communicative meaning of language. It can be compared to usage, which refers to the rules for making language and

3 An expression used by the eminent scholar Pr. Joseph Owona, one time Secretary General at the presidency, and today appointed member of the Constitutional council and from the Beti tribe. the structures we use to make it.

Particular interest here is to collect sample utterances considered incontinent speech used by Cameroonians that denote tribalism, and hate discourse in an emerging democracy as Cameroon, which if left unchecked, stigmatizes the listener and can lead to social prejudice and verbal violence. Note that over this period of time, certain political and social events experienced by Cameroonians have brought along with them new concepts that are enriching the vocabulary and linguistic repertoire of a people and the entire contemporary Cameroon society.

Many scientists opine that the socio-political context has also contributed to the state of affairs and type of discourse in Cameroon English. It is useful to underscore that contemporary Cameroon is characterized by a recurrence of social injustice, elections contestations, social and constitutional reforms, the Anglophone crises, insecurity, Boko Haram terrorist insurgence, poor governance, marginalization, lack of rigour, falling moral standards, corruption, alleged human rights abuse, and press liberty, constitute serious challenges to democracy and development in an emerging society as Cameroon. Such an atmosphere breeds contempt and animosity reflected in the language forms its members know and are available for use. This situation, characterized by misunderstandings, discontent, and stress, is fertile ground for the people with a multitude of languages and ethnic groups, and different viewpoints to develop attitudes of tribalism and hate discourse. Here, the speaker's choice of words can only be a reflection of his experiences and that of the society in which he is living. Sociologists, behaviourists and linguists alike have examined language use from different perspectives. Skinner [8], for example, believed that we do have such a thing as a mind, but that it is simply more productive to study observable behaviour rather than internal mental events. While he has focused on the language people were observed using, Chomsky [9] was interested in the underlying structure of language. What we study is what people implicitly know about their language. We do not study whether sentences abide by the 'rules' of grammar, but whether grammatical and ungrammatical sentences can be explained with the hypotheses we make. What we study is what people implicitly know about their language.

Orwell [13] examined the connection between political orthodoxies and the debasement of language and criticized the "ugly and inaccurate" style of written English of his time.

The phenomenon of tribalism and hate speech, exclusion and marginalization, which have been on a constant rise in Cameroon English speech has drawn the attention of many, all of who have decried the specific category of hate discourse based on tribal politics used to instrumentalized and weaponized the population for political gains in Cameroon. This sort of speech is characterized by hostile rhetorics of denigration and marginalization directed at certain minority groups as the Other or come-no-go. Tribalism, they strongly believe is the basis for hatred between peoples within the same country. Decrying this 
practice, they admit that there is an upsurge of hate speeches disseminated through different social media in Cameroon and notes that "Hate speech kills living together, sows seeds of fear, discord, hatred, distrust and creates social conflict," Even though French is the dominant language, English is used by many Cameroonians to communicate among themselves. The English language is not our mother's language, but as far as we are into it, we should try our best in using it the right way. Hence, an individual may use language in a particular way that affects the feelings, emotions, beliefs and ideas of the hearer. The idea that language is a means of communicating feelings, emotions and thoughts is nowadays held to be a partial truth, more misleading than illuminating. A more fruitful approach is to consider language, not only as an effective means of social control, but it can equally be used as an effective offensive technique in understanding the relationship between language, thought and reality Carroll et al [14]. This is the case with tribalism, politics and hate speech in contemporary Cameroon English.

The present investigation examines some specific lexical items and utterances related to tribal politics and hate discourse that have crept into contemporary Cameroon English vocabulary. Tribalism is the concept which attempts to naturally maintain a social network of its members, as they advocate for a particular way of thinking, acting and behaving in order to preserve and promote certain inherent social norms, traditional practices and values pertaining to their social group as opposed to concepts of nationhood. Based on relations of proximity and kinship, members of a given tribe tend to possess a strong feeling of social identity. In the sense used here, tribalism, derogatorily, is a type of discrimination or animosity based upon group differences. Tribalism can lead to bigotry and racism and, when taken to extremes, even war. Tribalism can endanger the whole nation in disunity and separation. It has caused nepotism, affected national cohesion and has caused misunderstanding between people. Aside these effects, there are other negative effects on marriages, sharing of opinion and even leadership roles.

This investigation sets out to observe real instances of naturally spontaneous speech used by Cameroonians, collect and examine typical samples of neologisms in order to analyze their structure and significance as meaningful communicative units of discourse, characteristic of contemporary English. The concern is with the speaker's linguistic competence and ability to form new words as the manifestation of concrete measurable reality and an abstraction of his social behavior within the Cameroon society. The study is diachronic, data-oriented and descriptive in nature considering the importance of studying new words, their forms and the varying meanings. From a pragmatic perspective, there is an intrinsic relationship between linguistics, sociology and psychology in understanding the impact of language use and variation in contemporary

4 Ngolle Ngolle, E (1991) "Ethnicity or Tribalism in African Politics, Implications for Democracy in Cameroon".

\section{Cameroon English.}

At the end of this investigation, readers would be able to understand the typical processes involved in word formation in a living language as Cameroon English, and use these linguistic abilities and processes to coin new words in their language. It will create greater awareness on the devastating effects of such speech forms to the tribe, person and the whole nation.

This investigation sets out to observe communicative competence, collect, examine and analyze specific speech acts commonly encountered in casual speech such as everyday conversations, TV talks, discussions, debates, the social media and newspapers on current issues as politics, the Anglophone crises, terrorism, corruption culture and society, tribalism and hate speech in Cameroon. The objective is to examine and describe different words and expressions used to manifest tribalism and hate speech in contemporary Cameroon English speech and their significance as utterances used with the intention to affect and stigmatize persons or groups or to hurt the hearer's feelings and emotions.

The significance of the study is that contemporary Cameroon with the advent of democracy and press liberty is a period of great challenges in democracy, freedom of speech, insecurity, social unrest and tribal conflicts, a situation that has perpetuated a corresponding upsurge in tribalism and hate discourse that is injurious, and devastating to social cohesion and living together. This study will help create awareness in the destructive effects of tribalism and hatred, vectors that destroy peace, harmony and prosperity of a nation.

Even though hate discourse may cause antagonism and violence, it nevertheless enriches English lexis, all of which have significantly enriched contemporary Cameroon English vocabulary system.

\section{Research Problem}

The problem is that many native speakers demonstrate tribal affiliation and service to their ethnic group above the love for the nation and serve general interest and not ethnocentricism. Moreover, there is a great upsurge in hate speech, as a result of debasement in language, where individual members attempt to disguise their intentions behind of the type of utterances and expressions they use. An overview of such expressions reveals that in Cameroon tribalism, politics, and hate speech seem inseparable in the same way as words and meaning are interrelated. When politicians use the notion of tribe for self and personal interest, there is bound to be animosity and tribal interest takes precedence over national interest hence any opposition to becomes detestable as speakers tend to use "pretentious diction" and "meaningless words". "Pretentious diction" is used to make biases look impartial and scientific, while "meaningless words" are used to stop the reader from seeing the point of the statement. In certain instances of language use, it is normal to come across words, expressions and long passages which are almost completely lacking in meaning. 
Language is a political issue, and the sloven use of language and cliches make it easier for those in power to deliberately use misleading language to hide unpleasant political facts. Note the homophony in Republique and 'Ruepublique', in which it refers to a system of governance with strong institutions and legality, while the latter signifies public streets; the law in the streets is jungle law and illegal within a Republican system as that of Cameroon.

The problem is that though Orwell (2006) describes the language of politics as "pretentious diction" and "meaningless words", hate discourse is not just "Pretentious diction" used to make biases look impartial, but to stop the listener from seeing the point of the statement. To use expressions as come-no-go, Bami, anglo, Bamenda, Béti, politique civilisée, are examples of hate discourse is injurious and denigrating to persons and groups of people. These expressions are not easy to understand except they are placed in their social and linguistic context. The meaning of the expression politique civilisée in French; « Tant que les hooligan Tontinards ne feront pas de la politique civilisée, je ne les lâcherai pas !!! »/As long as the so-called hooligans who call themselves tontinards. do not play civilized politics, I will not let them free....' [my translation] may become visible. Note the menacing tone in the speaker's discourse when he swears. In certain kinds of casual speech, particularly in political speech, it is normal to come across long passages which are almost completely lacking in meaning," according to Orwell [13]. In the example above, the speaker deliberately chooses his words do not play civilized politics to caution his listeners, whom he categorizes as hooligans, who lack political tact and diplomacy. $\mathrm{He}$ consciously or unconsciously expresses his idea on the politics as a game, and reveals his hidden feelings, and emotions of disdain, tribalism and hatred. Today, local elites in the name of politics manipulate ethnic groups to influence elections and development in the democratic process. When speakers use expressions with multiple meanings, their senses might be mistakenly interpreted resulting in an over exaggeration of behaviour. Orwell believed that the language used as politique civilisée, is necessarily vague or meaningless expressions because it is intended to hide the truth rather than express it. This unclear prose is a contagion which had spread to those who did not intend to hide the truth. The insincerity of the writer perpetuates the decline of the language as the people.

There is no exact and ready-made legal definition of "hate speech," but the United Nations Organization defines it as "any kind of communication in speech, writing or behaviour that attacks or uses pejorative discriminatory language to a person or a group on the basis of ethnicity, nationality, race, colour, descent, gender or other identity factor. It is considered "public speech that expresses hatred for someone or encourages violence towards a person or group of persons based on race, religion, sex, or sexual orientation." 'Hate' speech is any form of language use intended to hurt someone or a group, inflict pain, disorientate or destroy someone's state of mind. It destroys society and blocks the nation's progress., which if left unaddressed, can seriously lead to stigmatization, marginalization, frustration, rebellion, violence and hate crimes.

\section{Hypothesis}

The idea is that how we look at other people and the world is largely determined by our thought processes, and our language limits our thought process. It shows us how the different languages we speak shape our reality very differently and how because of this we respond to situations very differently. This is the situation with tribalism and hate discourse as people perceive reality differently. While some consider tribalism legitimate, others think that some users often exaggerate their view to debasement in their use of language. Though Orwell (2006) affirms that the decline of the English language comes from a never- ending cycle of foolish thoughts giving way to sloppy speech and writing, it eventually leads to more foolish thoughts including malpractices as tribalism and hate speech. Previous studies have demonstrated that language is a reflection of the speaker's mind, perception and behaviour. In his opinion, all issues are political issues, and politics itself is a mass of lies, evasions, folly, hatred and schizophrenia. When the general atmosphere is bad, language must suffer.

Thus, the assertion that we tend to see, hear and otherwise experience things very largely as we do because the language habits of our community predispose speakers of certain choices of interpretation is tenable. The Sapir-Whorf hypothesis, also known as the linguistic relativity hypothesis, refers to the proposal that the particular language one speaks influences the way one thinks about reality.

\section{Scope of Study}

Over the years, linguists have taken particular interest in phonology, morphology, grammar, syntax and lexis and little attention to aspects of semantics and pragmatics. In recent times, greater attention needs to be given to the producers and consumers of discourse as connected discourse or longer stretches of language in which context of use is paramount. If we consider language use as a form of social behavior, then the utterance is the essential materials for clothing the ideas, thoughts, beliefs and concepts shared by members of that society. Expressions like waajo kambo, bamendaman, frog, mouton, anglo, etc., designate different cultural references used pejoratively to describe people from different parts of Cameroon. To refer to a group of people as mouton is outrageous in the same way as to refer to a people in terms of their linguistic origin. Above all, such usage breeds hatred for considering a person as an animal, mouton. When examined more critically, these forms are considered insults and stigmatization.

This scope of study serves to set critical discourse analysis (CDA) off on the one hand from other kinds of discourse analysis, and from textlinguistics, pragmatics and sociolinguistics, on the other. 
More recently, applied sociolinguists such as Pennycook [15] and Fairclough [16] have in quite different ways developed this approach. Fairclough's [16] research uses a CDA approach to identify and expose the ways in which ideology and power are constantly instantiated and enacted in the familiar discourse of the media and of everyday interactions.

In the preceding lines, some basic concepts used need to be defined notably; tribalism, politics, hatred, Contemporary, English, and Usurpation.

The term 'tribalism' simply refers to the state of living together and sharing customs, patterns, beliefs and a sense of belonging to a tribe. In this investigation, the term 'tribalism' is a tendency to place one's ethnic loyalty, social identity, aspirations and cultural values above every other consideration. Tribalism implies the possession of a strong political, cultural or ethnic identity that separates members of one group from another group. Tribalism in practice can lead to bigotry and racism and, when stretched out of dimension, even to violence and war.

The term, 'politics' has a plethora of meanings. It refers to political science as a discipline that studies ways and techniques of ruling or governing a group of people to achieve a set of collective objectives. It designates 'the social relations involving intrigues to gain or exercise authority or power. The idea describes 'politics' in terms of the activities and affairs involved in managing a state or a people.

Hatred' denotes the condition or emotional state of intense dislike; a feeling of dislike so strong that it demands action.' It comes as a conditioned emotional response, (CER), conditioned emotion, anger, choleric, fear, fearful, fright, fear The meaning here includes abhorrence, abomination, detestation, execration, loathing, murderousness, despising, hostility, enmity, ill will, animosity, antagonism, aggression, belligerence, resentment, bitterness, rancor, heartburning, sulkiness, grudge, score-settling, grievance, envy, covetousness, malevolence, malignity, malice, venomous, vindictiveness, and vengefulness. It is important to note such description of different speaker's emotional state of mind fits the sample data of utterances collected and analyzed and subsequently described as hate discourse. The term, 'Hate' speech describe any form of language use intended to hurt someone or a group, inflict pain, disorientate or destroy someone's state. There is no exact legal definition of "hate speech", the United Nations Organization defines it as, "any kind of communication in speech, writing or behaviour that attacks or uses pejorative discriminatory language to a person or a group on the basis of ethnicity, nationality, race, colour, descent, gender or other identity factor. 'Hate' speech is considered "public speech that expresses hatred for someone or encourages violence towards a person or group based on race, religion, sex, or sexual orientation". Hate speech is synonymous linguistic impoliteness, abhorrence, detestation, loathing, despising, hostility, enmity, animosity, antagonism, aggression, resentment, bitterness, rancor, sulkiness, grudge, score-settling, grievance, envy, malevolence, malice, vindictiveness, and vengance.
In most situations frequently encountered, when left unaddressed seriously, it leads to aggression and violence as observed in this attitude in this declaration culled from a newspaper; Atanga Nji s'attaque à MTN et Orange,/Atanga $\mathrm{Nji}$ attacks MTN and Orange [my translation] Kamto \& Atanga Nji, Duel de Sang/Kamto \& Atanga Nji, a bloody duel [my translation] for example, make use of the verbs attacks and duel which are synonymous to hatred, antagonism, aggression, detestation, loathing, despising, hostility, enmity, resentment, bitterness and rancor. Note that such synonyms describe a speaker's emotional state of mind that may come as a conditioned emotional response (CER) of anger, fear and fright. Hatred' denotes the human condition or emotional state of intense dislike; a feeling of dislike so strong that it demands action. Hate speech is a menace to democratic values, living together and peace and destroys social cohesion. Such speech acts hurt and can incite hearers to hostility and violence.

On its part, the term 'Contemporary' signifies pertaining to the present, or modern- day period between 1990 till date in contrast to Old English (OE), or Middle English (ME) period. Used in this sense, contemporary Cameroon English speech designates a variety of English used and acceptable as such within Cameroon. It is mutually intelligible in phonology, grammatical structures and semantics to the population, characterized by the mixture of different languages used in Cameroon as French, Cameroon Pidgin English, Camfranglais, and the grammatical structures of some local languages in the present Cameroon society.

The term 'Usurpation' denotes entry into another's property without outright permission; it is a wrongful conduct, trespassing, encroachment, infringement, violation, malpractice, and intrusion into one's personality. A usurper is a person who acts without any moral scruples. It is understood as a wrongful act, deed, or human action that is perverse, injurious, and unfair. Here, it is seen as human activity and practice observed within the contemporary Cameroon society. Linguistic usurpation explains the use of expressions with the intention to hurt, injure, and brutalize a person's emotional and psychological state.

\section{Methodology}

Several studies in ethnomethodology have inspired a wide range of important theoretical and empirical work in the social sciences and concerns with language in particular, centre on issues of tribalism and hate discourse among others.

Authentic quantitative and qualitative data were obtained from reliable informants including researchers, lecturers, MPs, businessmen, traditional chiefs, opinion holders, journalists, etc. Data was obtained from real life instances of casual conversations, interviews, radio and TV debates, news broadcast, postages and publications on social media, newspapers and magazines, which expose concerns of tribalism and politics. On different media, people express their opinions on burning these issues affecting the society.

The present corpus of contemporary English in Cameroon is 
comprised of extracts from spontaneous natural conversations and speeches from a wide spectrum of informants in English, French, Cameroon Pidgin English and Cameroon home languages. Texts from casual conversations, debates and speeches were collected from informants for analysis.

In many instances recorded, speakers hardly understood that they were actually using hate discourse. To them, they were just speaking out their mind. The questionnaires used push the speakers to express their opinion on different sensitive burning issues among which we have tribalism and hate discourse in Cameroon.

The ethnomethodologists, notably Saville-Troike [17] studied conversational discourse using the ethnography of communication and Garfinkel [18] put forth this distinct approach to sociological inquiry, which lays down basic principles for observing the way native speakers use language in their everyday face-to-face interpersonal conversational discourse. He focuses on analyzing the way members in a given speech community make sense of their everyday encounter and routine in life as a social fact.

A combination of relevant ethnographic, sociological and linguistic methods, have been developed to account for society as component parts, each in its own right. In other words, ethnomethodology is interested in whether or not the accounts given by sociologists are accurate, but rather in the useful and accurate methods developed to convey those accounts on what native speakers say and what they do with language in a meaningful way.

Carroll et al [14), on reflections on language and meaning, cites Whorf (1897-1941), who attempted to grasp the relationship between human language and human thinking: how language can shape man's innermost thoughts on the thesis that our perception of the world and our ways of thinking about it are deeply influenced by the structure of the languages we have learnt and speak. These structures account for the different ways by which the people under study think and behave in social interactions (e.g., you don't have to ask permission to use the word 'come-no-go' to a fellow Cameroonian on national broadcasting stations). To call someone 'come-no-go' seems to come out naturally as the feeling of tribalism or hatred for someone not speaking your language grips you. One is not taught in school that when you see $\mathrm{X}$ or $\mathrm{Y}$, he is a come-no-go. Linguists draw from the accounts provided by ethnomethodologists, and sociologists to describe and analyze the different utterances speakers use during social behavior and their underlying senses, aspects which are often taken for granted by sociologists. While ethnomethodology is often seen as being far removed from more mainstream sociology, it has proven to be influential in linguistic descriptions of this sort. For instance, ethnomethodology notes that words are reliant for their meaning in their linguistic contexts, but discourse meaning is based on the context in which they are used.

\section{Theoretical Framework}

The Sapir-Whorf hypothesis asserts that an individual's thoughts and actions are determined by the language or languages that individual speaks. This theory states that the structure of a language determines or greatly influences our thoughts and behavior characteristic of the culture in which it is spoken. In other words, how we look at the world is largely determined by our thought processes, and our language limits our thought process. It shows that the different languages we speak shape our reality very differently and because of this we respond to situations very differently.

In order to describe and analyze communication, it is necessary to deal with discrete units of some kind, with communicative activities that have recognizable boundaries three of such units suggested are situation, event, and act. The communicative situation is the context within which communication occurs. Examples include a conversation, a political speech during campaign, or a class in school. The communicative event is the basic unit for descriptive purposes. A single event is defined by a unified set of components throughout, beginning with the same general purpose of communication, the same general topic, and involving the same participants, generally using the same language variety, maintaining the same tone or key and the same rules for interaction, in the same setting. The study of speech acts within linguistic theory is the basis for this level of analysis, but must be extended to account for a broader range of phenomena within the ethnography of communication, and to allow for possible differences with regard to what segments of language are considered basic functional units by members of different speech communities. It is suggested that textual analysis needs to be based upon a multifunctional theory of language such as systematicfunctional linguistics. It examines utterances and their constituent parts paying particular attention to these as communicative acts, deeds, human actions, and social fact.

The communicative act is generally coterminous with a single interactional function, such as a referential statement, a request, or a command, and maybe either verbal or nonverbal. For example, not only may a request take several verbal forms (I'd like a pen and Do you have a pen? as well as May I please have a pen?), but it may be expressed by raised eyebrows and a "questioning" look, or by a longing sigh. In the context of a communicative event, even silence may be an intentional and conventional communicative act, and used to question, promise, deny, warn, insult, request, or command. Notes Saville-Troike [17]. The event as a unit for analysis is important in part so that observations made at different times will be comparable, and so that generalizations can be made about patterns of communication within a constant context. To adequately analyze the present data, the critical discourse analysis is central as it investigates the component parts of a whole and their relations in making up the whole. It deals with analytical thinking by the abstract separation of a whole into its constituent parts in order to understand the parts and their relations. In fact, analysis is the use of a set of techniques for exploring underlying motives in using language and a method of treating various kinds of texts; based on Freud's psychoanalytical theories, it deals with 
human thought processes. The functionalist theory attempts to explain the fact that the use of hate speech is a conscious form of behavior and speech is a conscious social behaviour.

The pragmatic theory has emphasized on analyzing utterances from their context of use by providing a platform that establishes an intricate relationship between what people say, their perception of reality and the way meaning is derived from these elements. Therefore, sociopragmatics is an empirical approach to describe speech as social reality, i.e., what is said and what is meant and deals with the meaning of an utterance by considering its component parts from the whole context as a unit of analysis. The fact is that the 'real world' is, to a large extent, unconsciously built up of constituent parts that can only be understood when broken down as parts of the whole. In this case, the utterances under study are communicative units of meaning restricted within the Cameroon speech community.

Thus, sociopragmatics involves the use of a set of both grammatical and sociological techniques capable of exploring underlying motives of what people say and what is meant to by what is said as a form of social behavior. Note that common expressions such as marabout, gadamayo, mouton, as well as waajo, for instance, are now being used all over Cameroon to designate people from the northern parts of Cameroon and other expressions as Anglo, Sardinard or tontinard, demonstrates the speaker underlying ethnic prejudice and antagonistic motives that cannot be understood by anyone since these are unobservable facts. The utterance, bamenda, for example, is a general term for a town in the northwest region of Cameroon, yet it is used to describe everybody from this region, talk less of classifying these people as anglo and separatists and today, used for members of the Anglophone minority community in Cameroon. To refer to a person as mouton, anglophone as if he represents a community or group of people is outrageous and heinous, mouton and anglo breed hatred in the same way as the negative and denigrating reference come-no-go giving this respectable people a poor image of their social and cultural identity as foreigners in their own country. Similarly, to call someone a bamendaman, is synonymous to someone who likes to criticize others and oppose things.

Note that individuals in a given speech community have a particular way of thinking and speaking perculiar to their society. Instead of focusing on semantics and what words mean, sociopragmatic descriptions focus on what people say and what they mean. In other words, analysis is based on the various things that people do with language in everyday conversation encounters when they speak. For example, to what extent do utterances as mouton, waajo, anglo, Comeno-go, suggest indignation and stigmatisation, similar to expressions as Sardinards and Tontinards that vaguely describe Cameroonians as hooligans and irresponsible citizens to the extent as to call some apprentis sorciers, oiseaux des mauvaises augures, vendeurs des illusions etc.

The concepts of tribalism and hate speech is indicative of intolerance and the lack of cooperation among speakers. Hatred emphasizes on differences and disagreement and for the most part, speakers tend to conceal their deep intentions. Grice (1975: 26-30) [19], therefore postulates the Cooperative Principle and provides four maxims specific to be co-operative in speech. It is common knowledge that in casual conversation, people are expected to generally follow these rules for efficient communication known as Cooperative Principle and summarized as follows;

1. -Maxim of Quality. Make your contribution true; so do not convey what you believe false or unjustified.

2. -Maxim of Quantity. Be as informative as required.

3. -Maxim of Relation. Be relevant.

4. -Maxim of Manner. Be perspicuous; so avoid obscurity and ambiguity, and strive for brevity and order.

In his view, these are not arbitrary conventions, but are instances of general rules governing rational, co-operative behavior during real instances of speech or conversation. For example, drawing from our corpus, Aisha asked John to help her out with an assignment. if John is helping Aisha with her English assignment, (co-operation) he will surely assist her with some relevant explanations rather than ask her to start doing it (irrelevance), not giving her all the books and materials needed (quantity), and appropriate ones (quality); he will do all this quickly and efficiently (manner).

The neo-Gricean theories have modified these principles to some extent, and Relevance theory replace them with a principle of communicative efficiency. The maxim of Relevance implicatures like (1) are thought to arise from the maxim of Relation. John would have infringed this maxim unless his contribution were relevant to the purpose of the conversation. If John is being cooperative, then he is trying to answer Aisha's initial worry. Given that working is incompatible with playing, for instance, it is inferred that John must have intended to communicate that he is not going for football practice. Grice [19] thought implicatures arise by flouting with any of these maxims. This happens when what a co-operating speaker says so patently violates a maxim that the hearer must infer that the speaker means something different. Irony is thought to arise from flouting the maxim of Quality. This is the case with hate speech as most speakers tend to flout with the rules and ethics of maintaining good social relationships. Someone who uses speech that is considered ugly, and debasing, insulting, sloven as evil omens, sellers of illusions, operation Bamenda clean, wajo, gadamayo, autochthones, anglo, come-no-go, gadamayo, sorcerer etc., are harmful and injurious speech acts that do not merely depict hate discourse, qualifying people with words like evil, omen, deceitful, birds, sellers, illusions, survival, apprentis, sorcerers, petits parti, un glissément de date, but these words lack political vitality, and are void of meaning in the sense that they do not point to any convincing ideas, but are hardly even able to do so except by denigrating human beings. Note that such political language is designed to make lies sound truthful and murder respectable, even when they are vague and meaningless because they are intended to hide the truth rather than express it and to conceal the speaker's thoughts from himself, affirms Orwell [13]. Note the level of hatred expressed in this declaration from the 
corpus;

J'en profite pour dire a mes fréres du centre, qu'ils ont interet a rester tranquille,.. la plus part des difficultés que nous rencontrons viennent de nos fréres de la région du centre. L'homme Béti est forcément parraseux, jaloux, malhonnéte, cynique, et merchant ${ }^{5} /$ take this opportunity to tell my brothers of the Centre that it is in their interest to remain silent...Many of the challenges we encounter come from our brothers of the centre region. The Béti is essentially lazy, jaloused, cynical and dishonest and wicked. (my translation), using synonyms for deep hatred and ironically calls them 'my Béti brothers,' later, the same speaker intimates that les gens de l'ouest, vous etes des pauvres types. ${ }^{6}$ Idem/People from the west region, you are poor people. (my translation) Having described the Béti as a lazy, jealous, dishonest, cynical and wicked group of people he goes on to say those from the west region are poor'. By using these indignation and violent utterances to blast different groups of people, the speaker flouts with several co-operative maxims of ethics and morality. Even though a language is used to communicate the speaker's ideas, his choice of words reveals the speaker's feelings and emotions on the subject. In his declarations, and for reasons of personal interest, the speaker stigmatizes the Béti as well as the Bamiléké revealing his deep sense of tribalism and hatred for them.

Grice [19] proposes that many aspects of a "speaker's meaning" result from the assumption that the participants in a conversation have a perfect knowledge of the language and are cooperating in order to reach mutual goals - or at least pretend to do so.

In this circumstance, the speaker:

1) Pretends to be a stranger in his own land

2) blatantly hurts and segregates his 'brothers'

3) attempts to bargain for self or group interest and not national interest

a description which can be qualified either as tribalistic or the use of hate discourse. Though from a linguistic perspective, these words enrich contemporary Cameroon English no doubt, a critical discourse analysis interprets it to breed marginalization, stigmatization, injurious and consequently a form of hate speech.

Based on the theory of implicature, Grice [19] asserts that it denotes either (I) the act of meaning or implying one thing by saying something else, or (ii) the object of that act. The concept of 'act' refers to the directly observable action performed in the instance of use speech in an event as the intended and interpreted meaning of behavior. Implicatures can be determined by sentence meaning or by conversational context, and can be conventional (in different senses) or unconventional. His aim has been to understand "speaker's meaning"-what someone means by using a specific utteranceas well as that which arises from "sentence meaning"- the

5. This declaration was made by a local Beti elite, and business magnet, Jean Pierre Amougou Belinga, PDG of group Anecdote and Vision 4 and vision Finance, on Vision 4 TV, 1 of July 2020.

6. Essingan, 3 July, 2020. literal (form) meaning of an utterance provided for by a set of beliefs and experiences in the real world. Rather than focusing so much on structure and what words mean, focus on what people mean. In other words, focus is on the various things that people do with words to achieve their objectives in speech.

By extension, Grice [19] developed an influential theory to explain and predict conversational implicatures. The Cooperative Principles and associated maxims developed play a central role in understanding language use, and providing an approach that digs to understand the speaker's intended meaning known as theory of implicature.

In addition to identifying the phenomenon of implicature, and classifying its types, these principles are designed to explain and predict conversational implicatures and to describe how they are manifested and understood in every day conversations. "Implicature" denotes either (i) the act of meaning or implying one thing by saying something else, or (ii) the object of that act. Implicatures can be determined by sentence meaning or by conversational context, and can be conventional (in different senses) or unconventional. Figures of speech such as the metaphor and irony provide familiar examples, as do loose use and damning with faint praise. Implicature serves a variety of goals: communication, maintaining good social relations, misleading without lying, style, and verbal efficiency. Knowledge of common forms of implicature is acquired alongside with one's native language used in real instances of speech as conversations. Conversational implicatures have become one of the principal subjects of pragmatics. Over the years, pragmatics the study of the use and meaning of utterances to their situations - has become a more and more important branch of linguistics, as the inadequacies of a purely formalist, abstract approach to the study of language have become more evident. In terms of the former, Leech [21] and others were interested in analyzing linguistic impoliteness, aggression, and mock politeness as well as mock impoliteness among the topics regularly addressed. His model studies linguistic communication in terms of communicative goals and principles of 'good communicative behaviour'. Thus, the use of declarative speech acts 'laziness, untrustworthiness, cynical and hypocrisy reveal the unco-operative relationship existing between sons and daughters of the Béti community as a result of struggle for power, political and economic individual supremacy.

Sapir-Whorf cited in Lucy [22] strongly holds that language plays a powerful role in shaping human consciousness, affecting everything from private thought and perception to larger patterns of behavior in society, ultimately allowing members of any given speech community to arrive at a shared sense of social reality. The structure of a language determines and greatly influences the modes of thought and behavior characteristic of the culture in which it is spoken. They believe that if an individual's thoughts, words and actions are determined by the language the individual speaks, then language influences thoughts and behaviour, fascinated by both psychological and cultural aspects of implied 
meaning in words as the case with contemporary Cameroon English discourse.

The study of a speaker's intended meaning and implicature is included in pragmatics, and covers the broad range of speech acts performed by using words and sentences. Austin's [21] study of speech acts, presuppositions and how to do things with words is fundamental in understanding what speakers do with language.

The ethnographic, semantic and pragmatic approaches to language use are helpful tools that help to succinctly bring out a better understanding of the pragmatic relationship between such utterances used to depict tribalism, politics and hate discourse in contemporary Cameroon English speech.

\section{Contemporary Cameroon English}

All over the planet people are familiar with English in this era of mass communication. It is the world's second largest native language. It is believed that over one billion people worldwide are currently learning English. English can be at least understood almost everywhere among scholars and educated people, as it is the most widely used language in the media in the world, and the language of cinema, Television, pop music, diplomacy, literature, social conversations, commerce and transactions and the computer world. It is also important because it is most common language spoken everywhere. English has now achieved the global status that it is quickly becoming the world's most spoken international language, therefore anyone who wants to progress in the world needs to be able to write, read, speak and understand English, Selma [23]. Hence, over the years, there has been a rapid development of new varieties of English different from Standard British English based on certain slight peculiarities in pronunciation, grammatical structures and vocabulary often described as new Englishes including British or Welsh English, Canadian English, American English, Australian English, West African English, Nigerian English, Ghanaian English etc. It is in this light that one can also talk of Cameroon English speech as a variety that also shares certain phonological, grammatical and semantic features typical of the mainstream standard English but regional.

Even in countries and speech communities where other languages are the dominant media of communication, substandard English remains widely used and accepted despite the multilingual and culturally diversified context like Cameroon with two official languages, English and French, a pidgin English and over 275 existing dialects. Among Cameroonians, English has become an ideal language for phatic communion; expressing people's ideas, feelings and emotions. Contemporary Cameroon English is a variety of English that is mutually intelligible to its users and characterized by a mixture of French, Cameroon Pidgin English, local languages, and Camfranglais, as different linguistic resources available to be used by a Cameroonian for communication purposes, in different situations. Despite the linguistically diversified index and its interculturality, this variety is specific to Cameroonians as Cameroon English, used, accepted and understood by a majority of Cameroonians of all walks of life. Words as Come-no-go, ambazonised, Kamtogate. Deidogate, Biyayist, Gargarise, tonton gourou Maurika, General Mad dog, ruepublique, antiSardinard, apprentis sorciers, glissement de date, petit parti, composante sociologique, where a Beti will say 'mes freres' and at the same time, he lambasts them as, Parresseux, Jaloux, cynique merchants, or pauvres, there is cause for concern on how people use language. Orwell says that this decline is self-perpetuating. Many of these are used without knowledge of their meaning, impact and far reaching consequences. Note that English and French are taught as compulsory subjects in schools and in public examinations. They are used in Cameroon administration, parliament, senate, churches, music, films, literature, etc. So intimate is the relationship between a language and the people who speak it that the two can scarcely be thought of apart. Though Cameroonians of both English (Anglophones) and French expressions (Francophones) live the same realities, they perceive things quite differently. A language lives only so long as there are people who speak it and use it as their mode of social, political and cultural expression, and its greatness is only that given by its people. This is the variety collected, analyzed and described in this study as contemporary Cameroon English mentioned earlier. With the increase in the population, contemporary English, like all the other languages, is subject to that constant growth and decay which characterize all forms of life, and in one way or another, do contribute to the kind of debasing vocabulary speaker's use to express their thoughts and feelings characteristic of the present-day Cameroon English.

True, the English language is not our mother's language but as far as we are into it, we should try our best in using it the right way though no one is perfect that he may not make mistakes, as simple as it may appear. By examining the non-native speakers' underlying knowledge of how it is used, we get a better understanding of how the mind works: If language use is a window into the mind, it enables listeners share into his thoughts, emotions and feelings. When a language shares similar grammatical structures with other languages, and many common words, it is easier for its speakers to understand each other. As a result, Cameroon English speech also shares a great number of words with French, Cameroon Pidgin English and other native languages including autochtone, waajo, Kambo, bamendaman, Ngarbuh, etc. This points out that the English used in recent times and styled Cameroon English is somewhat familiar to anyone lives in Cameroon, and sorting out correct meaning is not a hindrance to understanding, but it would be strange to a foreigner. There are parts of the language which he feels he does not have to learn afresh, but perhaps learn with less efforts. To a greater extent, the advent of multiparty politics and democracy as well as press freedom in Cameroon have fueled tribalinguistics and hate discourse of the type currently observed within the contemporary Cameroon English. 


\section{Tribalinguistics}

The concept of tribalinguistics results from the practice whereby every sector of the political, social, economic and cultural life of Cameroonians is geared on tribal feelings of my people first in job opportunities, appointments, business, political party, etc. Where one comes from and the language $\mathrm{s} / \mathrm{he}$ speaks is fundamental and affects one's political, economic and social status. This kind of speech, often used and accepted as normal in every facet of life, is characteristic of Cameroon English.

\subsection{Tribalism and Politics in Cameroon}

Tribalism and politics are scarcely separable in Cameroon as in most African countries, Schwarz [11], Rotberg [12]. The genesis of tribal politics in Cameroon is as old as the nation. However, a good example dates as far back as in 1955, when the outlawed Union of the Peoples of Cameroon (UPC), based largely among the Bamiléké and Bassa ethnic groups, in its quest for power, began an armed struggle for independence in French Cameroon. This rebellion continued, with diminishing intensity, even after independence. Thus, obviously, a language's influence widens as its speakers grow in power. The story with other political parties is similar. The Social Democratic Front (SDF), has its headquarters in the North west region, with its followers and sympathizers drawn largely from people who speak English, and is considered an Anglophone party. A majority of members of the Cameroon Renaissance Movement (CRM) headed by Pr. Kamto Maurice are from the West with many party militants from this region and ethnic group. In the same light, the Cameroon Democratic Union (CDU) of Adamou Ndam Njoya is predominantly made up of militants and sympathizers of the Bamoun dynasty.

To understand Orwell [13] worry on the debasement of language, in political rhetorics in contemporary Cameroon English, note that political arguments is largely infused with pretentious diction not intended to develop sound policies except words and expressions between individuals from different tribes or groups of people competing for political power and quarrelling over the best way to share fall outs of 'the national cake', positions and this fosters tribalism so fiercely as illustrated in this extract of a side comment in the campaign speech: 'vous devez surtout vous défier des chants trompeurs des oiseaux des mauvaises augures, ces marchands d'illusions qui n'ont pour projet que la déstabilisation ${ }^{7} /$ You must, above everything else, be careful of deceitful speech from birds of evil omen, these sellers of illusion, who have nothing else to offer except destabilisation [my translation] Mark that this extract of a political discourse is full of meaningless descriptive words, void of presenting any political agenda expected except injurious and vexatious utterances. In this kind of communication, particularly in politics, it is normal to come across long passages which are

7. For more on this, see Paul Biya's speech during the 2019 presidential election campaign speech, 03 May, 2019 on Twitter. almost completely lacking in substantial meaning as above but intended to ridicule the political opponents. Here, utterances like deceitful speech, birds of evil omens, sellers of illusions, as well as operation Bamenda clean, survival Cameroon, gadamayo, autochthones, anglo (phone), francophone, come-no-go, gadamayo, etc., in particular, with words like evil, omen, deceitful, birds, sellers, illusions, survival, phone, apprentis, sorciers, are injurious speech acts that lack political vitality, and are strictly meaningless, in the sense that they not only do not point to any convincing political agenda or plan of action, presented to convince the population to vote for a political party, and are there to discredit the opponent that depict hate discourse. Note that such political language, which, "is designed to make lies sound truthful and murder respectable, and to give an appearance of solidity to pure wind". He further refers to the use of debased language in politics as necessarily vague as it is intended to hide the truth rather than express it and to conceal the speaker's thoughts from himself and the people. If civilized politics, as someone describes such talk denotes a specific type of politics, Operation Bamenda clean' is a military operation to clean up the town. Anyone current with some of the latest human rights abuses on innocent population knows of the famous shooting down of some women and children in the Far North region and February 14, 2020 'Ngarbuh massacre' in Ntumbaw village, killing and burning down houses speak for themselves. Defenseless villages are killed, the inhabitants driven out into the bushes and hideouts, the huts set on fire with incendiary bullets, all in the political jargon of cleansing 'ratissage' or pacification operation clean up. Hundreds of peasants are robbed of their cattle and sent trudging along the roads with no more than they can carry as internally displaced persons; political jargons called it transfer of population or those living across the frontiers, not refugees fleeing from war. Are these examples of the effect of tribalism, ethnic cleansing and hate discourse?

Another glaring illustration of hate discourse is this declaration ${ }^{8}$ in which the speaker talks of the civil society activists in the diaspora as hooligans Tontinards declaring that Tant que les hooligans Tontinards ne feront pas de la politique civilisée, je ne les lâcherai pas !!! , / As long as the hoologan Tontinards do not practice civilised politics, I will not let them [my translation] Addressing the civil society activists, he vents out his anger in a sort of aggressive verbal construction, qualifying their attitude as those of hooligans, who practice uncivilised politics using physical force and not through a democratic process of the ballot box. He promises to face them squarely; " Tant que pour eux, il faut nécessairement couvrir d'injures les plus abjectes et obscènes ceux qui ont le malheur de ne pas être d'accord avec leur gourou tonton Maurika, ils m'auront en face / As long as they believe, it is necessary to copiously throw abject and

8. For more on this, see Pr. Mathias, Eric Owona Nguini, researcher at the Paul and Ango Ela Foundation on his facebook page Wednesday, 3 April, 2019. https//www.lebledparle.com.societe/1106891-. 
obscene insults at those who unfortunately happen not to share similar view points with their gourou tonton Maurika, they will see. [my translation] This declaration by a supporter of the system in place is a threat even to those with whom he shares different view points, and his use of the word 'Tonton' is quite significant to those familiar with the speaker and his relationship with who he describes as 'gourou Tonton Maurika ' giving it a satirical and neologistic twist. Further, notice the tone of hatred in his voice and choice of such words as d 'injures les plus abjectes et obscènes as he describes a political opponent as gourou tonton Maurika. insisting that: " Tant que leur positionnement politique sera basé sur l'instrumentalisation cynique des penchants ethnocentriques souvent portés jusqu'au summum de l'ethnofascisme, ils me trouveront sur leur chemin »// As long as their political position is based on cynical instrumentalisation of ethnocentric inclinations, often carried to extreme ethno-fascism, they will find me waiting at the cross-roads [my translation).

Note that expressions of this kind; cynical instrumentalization, ethnocentric inclinations and extreme ethno-fascism are used in a consciously pretentious way as in political language, each contestant uses the same techniques of tribalinguistics wherein he intends to weaken his opponents at all cost. That is, the person who uses pretentious dictions has his personal definitions of such utterances as those above, but allows his hearer to figure out their meaning by giving them varying meanings, which sometimes almost completely lacks in meaning to the hearers, a majority of whose level of education and understanding is below standard. How many voters of the population understand the meaning of such learned expressions as cynical instrumentalization, ethnocentric inclinations and extreme ethno-fascism? These expressions only go to hide deep concepts that may reveal the speaker's emotions and psychological state of mind and thoughts about those who equally do not share his political convictions. In short, these words as used in political art are strictly meaningless, in the sense that they not only do not point to any discoverable object, but are hardly even expected to do so by the speaker, what has been termed linguistic usurpation. Other similar expressions as politics, ethnocentric, ethnofascism, democracy, republic, tribal, enemies of the nation, justice, Operation Bamenda clean, destabilization, cynical instrumentalization, inclinations, each have several meanings which cannot be reconciled with one another with a rationale in all situations. In the cases of democracy, or republic, not only has been an agreed definition of the concept for several decades, but the attempt to make one is resisted from all sides. It is almost universally felt that when we call a country democratic or a group of people tribe, we are giving it strong positive attributes and praising it: consequently, the defenders of every kind of régime claim that it is a democracy, and fear that they might have to stop using that word if it were tied down to any one meaning in the same way as defenders of a republic or tribe would uphold loyalty and promotion of national or cultural norms to be primordial.
If not attempts to usurp their significance, utterances of this sort are often used in a consciously dishonest way to denote deep existential concepts as the euphemistic expression operation Bamenda clean, which, in order words, seems to hide intention to capture and disarm amba forces operating in this conflict zone characterized by kidnappings, killings, and assassinations, and the military is carrying out a clean-up campaign 'ratissage' aimed at wiping out any separatist groups in the town and region capable of being a hindrance to the 2020/2021 academic school reopening scheduled for October. This operation has witnessed a standstill of all social and economic activities in the town, rendering life difficult, as each time there are bullet exchanges, forcing its inhabitants to flee to neighbouring cities. Such phraseology is needed if one wants to name things without calling up mental pictures of them. The insincerity of the operation perpetuates the decline of the language as the government and particularly politicians, attempt to disguise their intentions behind euphemisms and convoluted phrasing.

The word ethno-fascism has now no meaning except in so far as it signifies 'something not desirable, but a usurpation. Many of these words are used without express knowledge of their meaning and impact on the society. That is, the person who uses them has his own private definition, but allows his hearer to think out the meaning as he so desires. Statements like unpatriotic, political positionings, are almost always made with intent to deceive the listener. Sometimes, tribal sentiments override national issues.

Justifying this deep-rooted concept of tribalism in Cameroon, let us examine this declaration in French: " Pendant 37 ans vous avez usé du tribalisme pour vous maintenir au pouvoir, pour monter les ethnies les unes contre les autres au détriment du vivre ensemble. Et c'est ainsi que vous avez maintenu le pouvoir tribal pendant 37 années. La preuve en 1984 vous avez monté les camerounais contre les nordistes, en 1992 vous avez monté les camerounais contre les anglophones et aujourd'hui vous essayez de monter les camerounais contre les bamilékés. Mais malchance pour vous le tour ci c'est le vrai tour. Les camerounais ont désormais compris votre jeu tribal'. ${ }^{9} /$ For 37 years, you have used tribalism to stay in power, mounting one ethnic group against the other to the detriment of living together. And that is how you have continued to remain in power for 37years. The prove is that in 1984, you people have manipulated Cameroonians against the northerners, in 1992. You again attempted to manipulate Cameroonians against the anglophones and today, you are trying to pit Cameroonians against the Bamiléké. Unfortunately, this time, it will not be easy. Cameroonians have become aware of this game.' [my translation] In his opinion, the speaker demonstrates that tribal politics uses such mean techniques as manipulation, division and hatred in consonance with Orwell [13] idea of 'foolish thoughts as the decline of the English language in

9 For more on this, see Dieudonné Essomba refuse d'accepter.. in cameroonweb.com, April 1, 2019 at 1.00 p.m. 
politics is self-perpetuating. He argues that it is easier to think with poor English because the language is in decline; and, as the language declines, "foolish" thoughts become even easier, reinforcing the original cause.

Once people speak in terms of Sawa, Bulu, Béti, Bamenda, nordist, anglo, Bamiléké, etc., reference is being made to tribal loyalty and not just to individuals. The word Bamendaman, which in principle, refers to someone from the town of Bamenda, the capital city of the North west region of Cameroon, describes every person from the English-speaking regions without distinction of North west and South west. Today, tribalism, the act and feeling of being attached to one's roots, culture, tradition and ethnic identity puts one's own ethnic group above every other consideration including that of the nation. Tribalism implies the possession of a strong cultural or ethnic identity that separates one member of a group from the members of another group. A practice that when taken to extremes, as is the case in Cameroon, leads to hatred, bigotry and segregation and, even violent conflicts and war. Tribalism, many argue, is the basis for hatred between peoples within a country. The words ambazonia, ambaboys, separatists, general Mad dog, General peaceplant, terrorist, for many English-speakers do carry specific meanings connected with the speaker's experiences of the conflict and atrocities witnessed in the Anglophone crises in NOSO and intensifying secessionists efforts. These words may have been existing but, they depict antagonism, hatred in Cameroon English speech.

Austin [21] argues that instead of focusing so much on semantics and what words mean, we should focus on what people mean. Is what we say what we mean or what we mean is what we say? In other words, linguistic analysts should focus on the various things that people do with speech or, to use language for. Words in a language are symbols by which man expresses his ideas, clothes his emotions and feelings of love, hatred and co-operates with others. we judging a person through the language he uses and his ethnic affinity, but sometimes in our thoughts we also misconstrue this judgement and tend to abuse them, using ugly and inaccurate language which often create prejudice and antagonism. The words we employ designate the way we think. speak and act from the things we perceive, and obviously the vocabulary of our language must keep pace with the advance of our knowledge, events and experiences with our surrounding environment, notes Baugh \& Cable [24]. Many Cameroonian speakers consider that the Anglophone or Francophone is a tribe, yet they ignore that these are the results of its historical development including differences in language, culture, values etc. Many people talk of the Anglophone crises as if political and social reforms are needed only by people of particular areas and not a democratic principle.

As earlier demonstrated, in using certain words with politics, there is a kind of linguistic usurpation or abused. In the case of the words, Sardinards, Brigarde Anti-Sardinards, Tontinards, etc., each has several meanings which cannot be reconciled with one another except perhaps attempts to camouflage hidden intended thoughts of hatred. The word 'sardine' from which Sardinard is derived from French sardine, Latin sardina; from the name of the island of Sardinia, Ancient Greek $\Sigma \alpha \rho \delta \varepsilon ́ \lambda \alpha$ (Sardela), is used to denote a species of the small deep orange-red variety of the chalcedony fish, often found in great numbers along the coasts of Europe; smaller and rounder than herring. In the context of Cameroon English, the speaker uses it to describe Cameroonian 'migrants to Europe, who, out of insufficient allowances, find themselves sharing a small room as a sardine container. To describe fellow Cameroonians in this term is denigrating, disdainful and disgustful. The words; Brigarde Anti-Sardinards and Hooligan Tontinards, refer to civil society activist groups in the diaspora go a long way to illustrate hate discourse based on tribal politics. It is due to the political conflicts in Cameroon that the diaspora is split into two main factions, the Sardinards or Brigarde Anti-Sardinards, who are followers and supporters of the ruling regime, while the other are supporters of the opposition leader notably, leader of the Cameroon Renaissance Movement (CRM) and others. ${ }^{10}$ Today, these two factions seem to oppose specific ethnic groups, thus creating a Béti/Bulu tribe in confrontation against the Bamiléké, on the one hand, some political elites from the North have also come up with operation 10 million nordistes as a pressure group, coupled with the anglophone crises, renders the situation quite complex, preparing for tribal-political manipulation, and division, all vying for political and economic power. Tribalism is always expressed by a particular penchant for excessive power and emotional attachment to one's own social group and cultural values and a readiness to defend these.

Many people wonder how is it that more than $80 \%$ of top government officials in the country are all from the south and/or centre regions appointed by the Béti regime. This is exactly the problem of tribalism in Cameroon, another subtle way to divide, manipulate and control public opinion. This situation will of course breed contempt against one group or tribe especially from anyone who harbours serious ambitions for political power. It creates animosity pushing the Bamiléké, Northerners or Anglophones to rise against this installed practice. Any keen observer will question how many influential Sawa, anglo, Northerner or Bamiléké ministers are in strategic government positions as the Béti, Bulu, Nanga etc.? After the 1982 aborted coup, till 1984, the Béti/Bulu hegemony set-up Cameroonians against the northerners; in 1992, at the advent of democracy, the same regime set-up the rest of Cameroonians against the Anglophones, manipulating their minds that SDF is an Anglophone affair and a North west political party which does not represent the interest of all Cameroonians to discredit and to fragilize them. Note that the goal of tribal politics is to set-up any strongly feared

10 The expression 'la composante sociologique' used by Atangana Manda, Director of the Observatoire médiatiques du Cameroon in MINCOM that has become an index of the argument that the regime in Yaounde cautions tribalism in politics. In a TV programme on Equinox, Le Debriefing' of 13/05/2020 where the archorman had as quest on set Hon. Bell, MP for Littoral, admits that appointments in Cameroon, the appointment of a PM as well as ministers and other important posts must consider, tribe and loyalty to sociological leanings of the individual as criteria not merit. 
group of Cameroonians against the other for the regime to play safe. The Cameroon Renaissance Movement is styled a Bamiléké party, using the image of Pr. Maurice Kamto to manipulate the minds of the people in order to discredit and destroy the Movement and argue that he is not fit to become president. If the Bétis in power claim to like the Sawas and Bamiléké as they pretend to do, more Sawas and Bamiléké should be appointed as top officials to replace the Béti at the head of important and strategic ministries like territorial administration, defense, Douala Ports authority etc. To hide behind this, the regime has left taxation department to one or two pro-regime officials from the southern Cameroon and northerners all over the country beginning with strategic centres and customs services, assisted by Bétis and never the Bamis on whom you now stigmatize as enemies of the nation. Today, power tussle at the helm of succession at the presidency is clannish and tribal. In a recent outing captioned on the social network, Dieudonne Essomba tance les pouvoirs public: Tout le monde accuse tout le monde et personne n'est responsable de rien, summarises the shrewd attitude of total resignation observed by a majority of Cameroonians with such frequently heard defeatist expressions as Ont va faire comment? le Cameroun c' est le Cameroun' to justify even the unjustifiable, evidence that the language used in politics is necessarily vague or meaningless because it is intended to hide the truth rather than express it. This unclear prose conceals the speaker's thoughts from himself and others. The long passage Tout le monde accuse tout le monde et personne n'est responsable de rien can be considered "pretentious diction" and "meaningless words" because it ends up by saying that no one is responsible for this situation and asking a rhetoric question Ont va faire comment/There is nothing one can do are "Pretentious diction" is used to make biases look impartial and to stop the listener from seeing the point of the statement. In this kind of expression, particularly in art of political conversation, it is normal to come across long passages which are almost completely lacking in meaning as in the unanswered reply; le Cameroun c'est le Cameroun.

\subsection{Tribalism and the Media}

The growth and expansion of the media in Cameroon, together with press liberty and freedom of speech are important elements in the propagation of tribalism and hate speech. Chomsky [10] examines language in politics with emphasis on two meanings of political terms, primary principle of international relations, and role of propaganda. The propaganda machine includes different media organs as audio-visual, print media, and the social media in recent years developing tribalism and pro-ethnic or anti-ethnic sentiments. The media in Cameroon, ${ }^{11}$ stands as a contributory factor to propagate tribalism and hate discourse,

11 Today, unlike 50 years ago, countless radio stations operate in Cameroon notably; CRTV-Radio, FM 102.5 Adamawa, The national station is the Cameroon Radio-Télévision (CRTV) and the CRTV Radio, Yaoundé FM 101, 2, Magic FM, Radio Sweet FM, CRTV Centre, Radio Kiss FM, Africa Radio, etc. for inciting different ideas, feelings and emotions. The greatest advantage of the radio, television, and written press ${ }^{12}$ is its power to reach a large number of listeners or mass of people all around the world in a very short period of time. They inform, educate and entertain the people and also influence the way people think, see and interpret the world.

It is therefore not strange that the media today continue to contribute enormously positively and negatively to enrich the lexemes with hate speech in Cameroon mediascape. The social media, newspapers and magazines do help to diffuse words and expressions of hate discourse within the people. Note that the speaker is conscious of the fact since the 2018 presidential elections, there has been increasing political tension and social unrest in Cameroon that has turn to tribal and ethnic conflicts. The expression Pour le camp d'en face, or those on the other side indicates words that depict opposition, discord, differing ideas, ideology and opinion. In as much as the members of this community live and experience such realities, their speech will be a direct reflection of what they live. A speaker will use language to fit his ideas. ${ }^{13}$

Certain media promote tribalism and hate speech as progovernment media, diffusing information on government actions, while others are styled pro-opposition as hardliners. Debates and talk shows on different television stations reveal different opinions of the people, feelings of tribalism and hate speech, some full of verbal invectives and heated verbal exchanges, which can be described by uncordial; 'Droit de Response' of Equinox TV and 'Canal Presse' of Canal 2 TV are illustrative of heated debates on burning issues as embezzlement, corruption, tribalism, and hate speech continue to preoccupy Cameroonians. The Cameroon press deals with such speech daily as they organize debates, interactive programmes during which Cameroonians are invited as guests to share their opinions on these burning issues. The media has the power to manipulate public opinion and make them change their views. As in every aspect, the audio-visual media plays the most strategic role in organizing and shaping public opinion on this issue. Known as the fourth power after the executive, legislative and judiciary powers in politics, the mass media plays an important role to inform and sensitize the population on issues negatively affecting the Cameroon society as tribalism and hate discourse. Journalists inform the population on state of things and may incite, excite or play low on crucial issues. The mass media can strongly influence public opinions to like and dislike, regarding many important issues, views and

12. The written press in Cameroon includes; Cameroon Tribune, Défis Actuels, Emergence, Essingan, Info Matin, Intégration, Jeune Afrique, La Météo, Le Jour Le Pélican, Le Soir, L'Oeil du Sahel, Mutations, The Guardian Post, The Info, The SUN, The Post. etc.

It further includes advertisement, movies, documentaries, Opera News, Facebook, whatsapp, twitter, Instagram, and other social network, and magazines.

13. For more on this, See François Gaël Mbala (Stagiaire) who quotes Pr. Mathias Eric Owona Nguini: « Tant que les hooligans Tontinards ne feront pas de la politique civilisée, je ne les lâcherai pas » in lebledparle.com. April 3, 2019 at 1: 00 PM. 
behaviors such as tribalism and hate discourse.

Media reports are so strong that they can modify the perception of the population, incite into, calm or refrain the people from certain violent course of action. Note the role and impact of tribalism and hate propaganda between the Rwandan Hutus and Tutsis on the 'Radio Mille Collines' in 1972 leading to the Rwandan genocide of thousands of Tutsis Thus, the newspaper L'Avenir, in the form of a question captions the idea of tribalism as; Les Bamilékés sont-ils indésirables? as an incentive strong enough to rebellion.

The French word Republique from Latin 'rēs publica' ("republic"), with rēs ("thing") + pūblica ("public"); literally, translated as a thing of the public or concerns of or public affair runs through the concept of the 'public', people or the population being at the centre of governance has, as a result of the series of protests experienced in Cameroon after the 2018 presidential election, taken a completely subtle sense of the word to 'rue public' or 'public street' described as the public in the streets in Cameroon. Originally, 'Republicanism,' which is a political system of governance in which the supreme power lies in an elected body of citizens as representatives and are governed through the rule of republican laws. It is a form of government whose head of state is not a monarchy, but an elected president. With perpetual contestation of elections and protests, the vanguished and opposition leaders, out of frustration and anger, have developed hatred and this is evident in their speech for sometimes now in Cameroon. The people, in their attempt to contest, spend more of their time in the street protests giving rise to the word 'rue public' to mean the law is in the streets and not in the hands of the elected government and its institutions. Members of Cameroon People's Party devised the concept known as 'Black Friday' or 'vendrédi noirs', as a means to pressurize the government put an end to the anglophone crises, and similarly, members of other parties organize what they called marches blanches ${ }^{14}$, a concept developed by CRM to revendicate hold-up victory, which led to the arrest and imprisonment of over 200 party militants. This breeds bitterness and antagonism. Today, the same party has come up with la marche pacifique, a political usurpation with the hidden intention to oust the president and regime in place, an antagonistic situation of tension, fear, insecurity, uncertainty as a result of tribalism and general hatred.

Chomsky (2004) posits that the primary principle of international relations' theory is that governments act to protect their security. Security for the population? No. They act in many ways to harm the population, easy to show that for their own populations as well.

Literal meaning of democracy lies in its core principles: power, thus control is vested in the people as decision-making body who choose their representatives in the house of

14 See La Marche blanche of 26 January 2019, organized by members of the $\mathrm{CRM}$ at the national and international levels (Douala, Yaounde, West, Paris, Berlin, Canada, etc.) to protest against what they called 'Non to Hold-up CAN' and a restitution of the supposed election victory.
Parliament as the legislative body and so on, that's literal meaning. But the way it really operates as a system is radically the opposite - absolutist control is from the top, virtually no effective participation from the grassroot except bought over to confirm top to bottom decisions. Take democracy. Democracy is said to be a system of government by and for the people that's what the people hail. When we look at the actual meaning, say in Cameroon, with its advanced model of a stale decentralized democracy, about $70 \%$ of the population, lower 70 percent on the income scale, have no influence whatsoever on important political and social decisions, no attention is paid to them. Attention increases slightly as you move up. When you get to the very top, people, through tribalism and nepotism get what they want, because they essentially in control and make policy.

However, social media have registered and reported several instances of verbal invectives assassination, and targeted destruction considered violent in tone from both the opposition, secessionists as well as the government forces. When some political parties describe the ruling regime as 'une dictature sanguine', and its supporters refer to such as Analphabétes politiques, les apprentis sorciers' and pietre politicien, to mean that these political players who lack political experience. Such words are pejorative in meaning. Thus, the media has become an efficient political propaganda instrument exploited by governments to infuse, change, manipulate, divide or twist public opinion. Exercising great impact of tribalism and loyalty to ethnic groups, elitist influence on state matters, one tends to question the role of patriotism and nationalism.

\section{Patriotism and Nationalism}

Nationalism as opposed to tribalism is a question of paying overwhelming importance to the nation not to tribal feelings. In Cameroon, the Far North region, for example, is peopled by the Arab Choa, Kotokos, Massa and toupouris, Northern Region is predominantly a preserve of the powerful Muslim Lamidat who have ruled there for decades and the Adamawa is composed of the Gbaya, Duru, Vute, Pheul, Mboum etc.. While the words patriotism and nationalism were once considered synonyms, they have taken on different connotations.

The word patriotism means "devoted love, support, and defense of one's country; national loyalty." the word a patriot could refer to "a member of a resistance movement, a freedom fighter. In contrast, feelings of nationalism are based on a belief that one's country is superior to all others. Historically, both patriotism and nationalism_were used roughly in the same way. But they significantly diverged along the way, and one has a much more positive connotation than the other. The term often brings to mind people directly involved with the defense of a nation, namely military service members as well as state and local government representatives. Soldiers who defend the country show exemplary patriotism. However, Patriotism generally has a positive connotation. It's used for various positive sentiments, 
attitudes, and actions involving loving one's country and serving the great good of all its people. However, fascist regimes have merged the fervor of nationalism with the notions of superiority, especially when it comes to ethnicity and religion. In such contexts, "patriots" can become those who happened to agree with you or look like you, and "traitors" those who do not. Patriots show more love and loyalty for the nation than to tribal affiliation in this sense of building a greater and stronger nation through integration than small tribes that believe in tribal loyalty. Here, it is a matter of misplaced values, ethics and morals.

\section{Possible Recommendations}

\subsection{Values and Moral}

Tribalism and hate discourse as examined and analyzed above are unethical, evil and pejorative as these depict frustration, anger, violence. Values are the rules which guide individual actions, and help members of a community make decisions about right and wrong, should and shouldn't, good and bad, while morals have a greater social element to values and tend to have a very broad acceptance. Morals are far more about good and bad than other values, thus we judge others more strongly on morals than their values. Moral values shape character and personality such as integrity, determination, loyalty, truthfulness, honesty, respect for others. Morals are therefore considered as one's motivation based on his ideas of right and wrong. To describe fellow tribesmen as lazy jealous, hypocritical, dishonest and wicked is outrageous and shows a lack of cooperation and disrespect in line with basic conversational and cooperative principles of speech that include such maxims as quality, quantity, relation, manner and relevance prescribed by philosophical linguists.

In philosophy, ethical behavior is determined by one's capacity for "good" behavior. The field of ethics or moral philosophy involves developing, defending, and recommending concepts of right and wrong behavior in human society. These concepts do not change as one's desires and motivations change. There is a universal basis in the mind that incorporates the basic principles and we set values to these principles based on the data we get by exposure to an unorganized and random set of utterances via interaction with other people.

Moral evil is any morally negative event caused by the intentional action or inaction of an agent, such as a person to hurt. Note that a people's values define what they want personally, but morals also define what the society around those people want for them. There are certain behaviour patterns that are desirable or undesirable depending on each given society. If love for one another, honesty, and respect for others are desirable values for building a strong social cohesion and good social relationship among members of a society, hate speech is undesirable in every human community. Basic moral behavior requires that members of the same speech community act in agreement in accordance to certain set out moral codes, values and standards. We all tend to demonstrate prosocial and moral behavior when we share, help, co-operate, communicate, act responsible, sympathize or otherwise demonstrate the ability to care about others.

\subsection{Counter and Prevent Hate Speech}

While government authorities have the primary responsibility to prevent, protect, dissuade and sensitize people from ethnic conflicts, atrocity, tribalism and linguistic violence, in the form of hate discourse, it is up to everyone to stop hatred towards each other and develop tolerance, love speech and preach forgiveness and love for country.

As ambassadors of goodwill, each one has the obligation to raise public awareness, educate friends and family on the dangers of tribal intolerance, manage our thoughts and speech responsibly so as to monitor the type of language we use with others such that hate speech and other forms of incitement to violence stops. It is also possible, in appliance to the articles in the law against the use of hate speech, reporting individual use or social media posts which spread any form of hate discourse in our society for necessary sanctions to compliers.

\section{Conclusion}

Important events in Cameroon in the last two decades have offered Cameroon linguists an excellent opportunity to observe, collect and study the relationship between tribalism, politics and hate discourse in Cameroon English discourse. Greater interest has been to analyze speech acts that denote hate discourse in Cameroon by identifying some typical utterances used in speech or writing with the intention to hurt the hearer or the other. Tribalism like hate discourse, have devastating effects on the individuals and the nation as a whole. General complain has been that tribalism has strongly infiltrated politics to the extent that power exercise is in the hands of people from particular tribes to the exclusion of others, which breed hatred. Note that more than half of English vocabulary is derived from Latin, German and some from Greek so is contemporary English and hate discourse derived from the complex linguistic situation of Cameroon. Good governance needs to be inclusive as other ethnic groups are relevant in the construction of a stronger nation and not through tribal political manipulations, division and hate discourse, unpatriotic and unethical values that defy social morals.

Often, speakers are not conscious that the words they use are powerful and does affect the listener's thoughts, moral and emotional state and feelings, perception, hence his actions and general behaviour. Love discourse is the one thing needful. Patriotism means devoted love, support, pride, and defense of one's country; national loyalty." Rather than write a caption as Les Bamiléké sont-ils indésirables? is provocation to people of the west. To build a stronger stable nation, all tribes in Cameroon must participate in an inclusive manner. It is also important to be conscious of the effects of the words we use during social interaction. Rather than, for example, call someone come-no-go, say brother, Sister. Rather than say, I don't care, use I, $m$ sorry', or Please, forgive me, I didn't 
mean to hurt you, I love you, etc. The soft way you address someone is very important. Note that speakers ought to change their mentality; to be sincere in our hearts, thoughts and actions towards others, and use concrete and clear speech to them instead of vagueness, and individuality over political conformity. Love conquers tribalism and hatred.

\section{References}

[1] Pennycook, A \& Makoni, S (2020). Innovations and Challenges in Applied Linguistics from the Global South, 1, Routledge, UK.

[2] Bitja'a Kody, Zachée Denis (1999) 'Problématique de la cohabitation des Langues". In: Mendo Ze, Gervais (éd.): Le français langue africaine: Enjeux et atouts pour la Francophonie. Paris: 80-95.

[3] Breton, R. and Fohtung, Bikia (1991) Atlas Administratif des langues nationales du Cameroun, Yaoundé, Paris.

[4] Boum Ndongo-Semengue, M. A. \& Sadembouo, Etienne (1999) "L'Atlas Linguistique Cameroun: les langues nationales et leur gestion". In: Mendo Ze, Gervais (ed.): Le français langue africaine: Enjeux et atouts pour la Francophonie. Paris: 67-79.

[5] Ethnologue (2017) Languages of the World; Twentieth Edition, Summary by country, Cameroon, the Summer Institute of Linguistics (SIL) International, www. ethnologue. Com.

[6] Wolf, H. (2001): English in Cameroon. Berlin, New York.

[7] Wolf, H. (1997): "Transcendence of Ethnic Boundaries: The Case of the Anglophones in Cameroon". Journal of Sociolinguistics 1 (3): 419-426.

[8] Skinner B. F. (1957) Verbal Behaviour, Appleton Century, New York, USA.

[9] Chomsky, N. (2012). with James McGilvray, The Science of Language, Cambridge University Press.

[10] Chomsky, N. (2004). Language and Politics Cambridge: Polity Press.
[11] Schwarz, W. (1966). Tribalism and Politics in Nigeria, The World Today, Vol. 22, No. 11, pp. 460-467.

[12] Rotberg, R, I. (1967). Tribalism and Politics in Zambia, African Report, New York, Vol. 12, Iss. 9, Dec. 1, p. 29.

[13] Orwell, G. (2006). Politics and the English Language. Peterborough: Broadview Press.,

[14] Carroll et al (2012). Language, Thought and Reality; Selected Writing of Benjamin Lee Whorf (2nd Ed.) The MIT Press.

[15] Pennycook AD (2016), The Cultural Politics of English as an International Language (Classic edition: 2016), Re-release (Classic Edition: 2016), Routledge, London.

[16] Fairclough, N. (1995). Critical Discourse Analysis: The critical study of language. London: Longman, 1995. Pp. 265.

[17] Saville-Stroike, M. (2013); The Ethnography of Communication. An Introduction ( $3^{\text {rd }}$ Ed.) Blackwell Publishing Ltd. 108 Cowley Road, Oxford, UK.

[18] Garfinkel, H. (2017) in Jacobson, Micheal Hviid; The Interactionist Imagination studying Meaning, Situation and Micro-Social Order, London, Palgrave-Macmillian, PP. 233261.

[19] Grice H. P. (1981) Studies in the Way of Words, Harvard University Press, 1989, 385 pp., Vol. 65. Issue 251.

[20] Austin J. L (1962) How to do Things with Words, Oxford University Press, Oxford.

[21] Leech, G. N. 1. (1983), Principles of Pragmatics, London, England, Longman, p. 11.

[22] Lucy, J. A. in International Encyclopedia of the Social \& Behavioural Sciences.

[23] Selma K. S. (2003) The Local Politics of Global English; Case studies in Linguistic Globalization, Lexington books, USA, The Rowman \& Littlefield Publishing Group Inc.

[24] Ngolle Ngolle, E (1991)"Ethnicity or Tribalism in African Politics, Implications for Democracy in Cameroon", CAMEROON. TRIBUNE, 27 May 1991, p. 7. 32. 